\title{
PENGGUNAAN JENIS PEMBALUT BERHUBUNGAN DENGAN KEJADIAN KEPUTIHAN
}

\author{
Windatania Mayasari ${ }^{\bowtie}$, Nety Taribuka, Zubaedah, Hawa Warhangan \\ Program Studi Kebidanan STIKes Maluku Husada
}

\begin{tabular}{l}
\hline ARTICLE INFO \\
\hline Article history \\
Submitted : 2021-01-05 \\
Revised : 2021-01-08 \\
Accepted : 2021-01-27 \\
\hline Keywords: \\
Pantyliner \\
Herbs napkins \\
Fluor albus \\
\hline Kata Kunci: \\
Pembalut \\
Pembalut herbal \\
Keputihan
\end{tabular}

\begin{abstract}
The use of pantyliner is one of the causes of vaginal discharge because pads use dangerous chemicals for the bleaching process, which produce dioxins that can trigger vaginal discharge. This study aims to determine the relationship between the use of sanitary napkins during menstruation in SMA. This study used a cross sectional approach. The population in this study were 144 high school students, the sample in this study were 105 female students. The sampling technique used was proposive sampling. Data collection was done by using questionnaires and forms related to data recording. Bivariate analysis using the chi squre statistical test. 105 respondents using herbal sanitary napkins in the highest normal incidence was $35(70 \%)$ and the lowest normal use of abnormal sanitary napkins was $12(21.8 \%)$. The incidence of abnormal vaginal discharge in ordinary sanitary napkins $55(100 \%)$ and the incidence of vaginal discharge in $50(100 \%)$ herbs napkins. There was a relationship between the use of this type of pantyliner and the incidence of flour albus in SMA, Waplau Subdistrict, Buru Regency. Penggunaan pembalut adalah salah satu penyebab dari keputihan karena pembalut menggunakan zat kimia berbahaya untuk proses pemutihan.yang menghasilkan zat dioxin yang dapat memicu munculnya keputihan. Penelitian ini bertujuan untuk mengetahui hubungan penggunaan jenis pembalut saat menstruasi pada siswi SMA. Penelitian ini menggunakan metode pendekatan cross sectional. Populasi dalam penelitian ini adalah siswi SMA yang berjumlah 144 orang, sampel dalam penelitian ini sebanyak 105 siswi. Teknik pengambilan sampel yang di gunakan adalah proposive sampling. Pengumpulan data data dengan cara menggunakan kuisioner dan formulir yang berkaitan dengan pencatatan data. Analisis bivariat menggunakan uji statistik chi squre. 105 responden penggunaan pembalut herbal pada kejadian normal tertinggi pada pembalut herbal $35(70 \%)$ dan penggunaan pembalut biasa tidak normal terendah pada pembalut biasa $12(21,8 \%)$. Kejadian keputihan tidak normal pada pembalut biasa 55 (100\%) dan kejadian keputihan pada pembalut herbal 50 (100\%). Ada hubungan penggunaan jenis pembalut dengan kejadian keputihan pada siswi SMA Kecamatan Waplau Kabupaten Buru.
\end{abstract}

$\triangle$ Corresponding Author:

Windatania Mayasari

Program Studi Kebidanan STIKes Maluku Husada

Telp. 081217752890

Email:windataniafaizin@gmail.com

\section{PENDAHULUAN}

Flour albus merupakan gejala keluarnya cairan putih, termasuk pengeluaran segala jenis cairan (yang bukan darah) dari vagina. Pengeluaran sedikit lendir dari liang senggama adalah normal, tetapi akan menjadi tidak normal apabila cairan putih tersebut cukup banyak sehingga membasahi celana dalam (Murtiastutik, 2010). Keputihan dapat terjadi pada keadaan yang normal (fisiologis), namun dapat juga merupakan gejala dari suatu kelainan yang harus diobati (patologis) (Clayton, 2008).
Saat ini, begitu banyak pilihan jenis pembalut wanita dengan keunggulan masingmasing. Aroma, warna dan bentuknya pun beragam. Selain itu banyak iklan di media massa yang menawarkan berbagai kelebihan pembalut wanita sehingga konsumen bingung memilih jenis pembalut yang akan dipakai saat menstruasi. Karena merek pembalut yang sangat banyak maka wanita gemar bergantiganti jenis maupun merek pembalut. Namun hal tersebut harus diwaspadai, sebab tidak semua jenis pembalut aman bagi kesehatan organ intim kaum perempuan. 
Beberapa macam pembalut yang menggunakan zat kimia berbahaya untuk proses pemutihan yang akan menghasilkan zat dioxin yang nantinya dapat menjadi pemicu munculnya masalah kesehatan organ genetalia wanita, apalagi jika kebersihan kurang terjaga, pembalut bisa menjadi pemicu munculnya keputihan, infeksi, iritasi bahkan radang vagina (Pribakti, 2012). Tujuan umum penelitian ini adalah untuk mengetahui apakah ada hubungan antara penggunaan jenis pembalut dengan kejadian keputihan.

\section{METODE PENELITIAN}

\section{Jenis Penelitian}

Jenis penelitian yang digunakan adalah penelitian analitik dengan desain cross sectional.

\section{Lokasi dan Waktu Penelitian}

Penelitian ini berlokasi di SMA Kecamatan Waplau Kabupaten Buru.

\section{Populasi dan Sampel}

Populasi dalam penelitian ini adalah seluruh siswi SMA di Kecamatan Waplau Kabupaten Buru yaitu sebanyak 144 orang. Penentuan besar sampel dapat dihitung dengan menggunakan rumus (Stanley Lemeshow, et al):

$$
\begin{aligned}
\mathrm{n} & =\frac{\mathrm{N} \cdot \mathrm{Z}^{2} \cdot \mathrm{p}(1-\mathrm{p})}{\mathrm{d}^{2}(\mathrm{~N}-1)+\mathrm{Z}^{2} \cdot \mathrm{p}(1-\mathrm{p})} \\
& =\frac{144 \cdot(1,96)^{2} \cdot 0,50 \cdot(1-0,50)}{(0,05)^{2} \cdot(144-1)+(1,96)^{2} \cdot 0,50 \cdot(1-0,50)} \\
& =\frac{144 \cdot(3,8416) \cdot 0,25}{(0,0025) \cdot(143)+(3,8416) \cdot 0,25} \\
& =\frac{138,2976}{0,3575+0,9604} \\
& =\frac{138,2976}{1,3179}=104,93=105 .
\end{aligned}
$$

Sampel dalam penelitian ini sebanyak 105 siswi. Teknik pengambilan sampel yang digunakan adalah proposive sampling.

\section{Pengumpulan Data}

Pengumpulan data dilakukan dengan menggunakan kuesioner yang dibagikan ke siswi SMA. Meminta responden mengisi kuesioner untuk mengetahui hubungan penggunaan jenis pembalut saat mensturasi dengan keputihan.

\section{Pengolahan dan Penyajian Data}

Pengolahan dan penyajian data dilakukan dengan menggunakan komputer program SPSS. Data disajikan dalam bentuk tabel distribusi frekuensi yang disertai narasi atau penjelasan.

\section{Analisis Data}

Uji statistik yang digunakan adalah Chi Square pada tingkat signifkan $(<0,05)$ Ho ditolak bila $p$-value $<0,05$ artinya data sampel mendukung adanya hubungan yang bermakna.

\section{HASIL PENELITIAN}

Berdasarkan tabel 1. dapat diketahui bahwa responden yang menggunakan pembalut herbal mengalami lebih sedikit kejadian keputihan tidak normal yaitu sebanyak 15 responden $(30 \%)$ sedangkan responden yang menggunakan pembalut biasa mengalami lebih banyak kejadian keputihan tidak normal yaitu sebanyak 43 orang responden $(78,2 \%)$. Dengan nilai $\mathrm{p}$ value 0,000 yang artinya adalah ada hubungan yang bermakna antara penggunaan jenis pembalut dengan kejadian keputihan.

\section{PEMBAHASAN}

Berdasarkan hasil penelitian diperoleh informasi bahwa responden yang menggunakan pembalut herbal mengalami lebih sedikit kejadian keputihan tidak normal sedangkan responden yang menggunakan pembalut biasa mengalami lebih banyak kejadian keputihan tidak normal. Dengan nilai $p$ value 0,000 karena nilai $p$ value $<0,05$ yang artinya ada hubungan yang signifikan antara penggunaan jenis pembalut dengan kejadian keputihan. Berdasarkan hal tersebut dapat disimpulkan bahwa penggunaan jenis pembalut berhubungan dengan kejadian keputihan pada siswi di Kecamatan Waplau Kabupaten Buru.

Penelitian ini sejalan dengan penelitaian yang dilakukan oleh (Susanti \& Wijaya, 2018), dengan jurnal perbedaan penggunaan pembalut, patyliner jenis biasa dan herbal dan kain dengan kejadian keputihan. Berdasarkan hasil penelitian didapatkan bahwa 
mahasiswa yang menggunakan pembalut dan pantyliner jenis biasa yang mengalami keputihan fisiologis sejumlah 25 orang $(65 \%)$ yang mengalami keputihan patologis sejumlah 1 orang $(2,6 \%)$ sedangkan yang tidak keputihan sejumlah 2 orang $(5,3 \%)$. Meskipun pantyliner merupakan salah satu faktor presdisposisi timbulnya keputihan tetapi dalam penelitian ini dihasilkan tidak ada pengaruh yang didapatkan dan nilai chi squre sebesar 0,452 yang lebih besar dari nilai $\mathrm{p}$ value 0,05 yang berarti Ho diterima dan tidak ada pengaruh penggunaan pembalut dan pantyliner terhadap kejadian keputihan.

Tabel 1. Hasil Uji Chi Square Jenis Pembalut dengan Kejadian Keputihan

\begin{tabular}{lccccccc}
\hline \multirow{3}{*}{ Jenis Pembalut } & \multicolumn{4}{c}{ Kejadian Keputihan } & \multicolumn{2}{c}{ Total } & \multirow{2}{*}{ P value } \\
\cline { 2 - 6 } & \multicolumn{2}{c}{ Normal } & \multicolumn{2}{c}{ Tidak Normal } & & & \\
\cline { 2 - 7 } & $\mathbf{n}$ & $\boldsymbol{\%}$ & $\mathbf{n}$ & $\boldsymbol{\%}$ & $\mathbf{n}$ & $\boldsymbol{\%}$ & \\
\hline Herbal & 35 & 70 & 15 & 30 & 50 & 100.0 & \multirow{2}{*}{0.000} \\
Biasa & 12 & 21.8 & 43 & 78.2 & 55 & 100.0 & \\
\hline Total & 47 & 44.8 & 58 & 55.2 & 105 & 100.0 & \\
\hline
\end{tabular}

Penelitian serupa yang dilakukan oleh (Wati et al., 2019) responden dengan penggunaan pembalut herbal memiliki pengetahuan yang tinggi dibandingkan dengan penggunaan pantyliner. Responden cenderung memiliki pengertian bahwa semakin lama penggunaan pembalut maka akan semakin merasakan khasiat herbal di dalamnya. Harga pembalut herbal yang relatif mahal 3 kali lipat dari harga pembalut biasa juga menjadi faktor pendorong wanita untuk berhemat dalam pemakaian. Sedangkan pembalut herbal lebih efektif menurunkan keputihan, penggunaan pantyliner dalam waktu yang lama akan menimbulkan kelembapan yang menjadi media tumbuhnya kuman.

Menurut (Persia et al., 2015), hal ini sesuai dengan pendapat ahli bahwa pemakaian pantyliner dengan frekuensi penggantian yang minimal setiap harinya akan lebih memungkinkan terjadinya flour albus kerena peningkatan suhu, kelembapan, dan $\mathrm{pH}$ yang telah lama memberikan waktu yang lebih potensial dan memungkinkan untuk mikroorganisme penyebab flour albus berkembang biak. Kejadian flour albus pada responden yang memakai pantyliner lebih tinggi dibandingkan dengan responden yang tidak memakai pantyliner.

Karakteristik yang berhubungan dengan kejadian keputihan berdasarkan hasil observasi yang dilakukan selama penelitian pada siswi SMA kecamatan Waplau tahun 2020, dari 105 responden angka kejadian keputihan tertinggi tidak normal dan terendah kejadian keputihan normal. Berdasarkan faktor yang didapat pada penelitian ini yaitu, kurangnya personal hygiene yang baik misalnya tidak membilas vagina dari depan ke belakang, tidak menggunakan celana dalam yang mudah menyerap keringat dan tidak mengganti $2 \mathrm{x}$ sehari atau terasa lembab.

Berdasarkan penelitian (Johar, Wiwin., Rejeki, Sri., Khayati, 2013) bahwa seorang remaja sebaiknya mengganti pembalut 2 kali sehari jika setelah mandi. pembalut perlu diganti sekitar empat sampai lima kali dalam sehari untuk menghindari pertumbuhan bakteri pada pembalut yang digunakan dan mencegah masuknya bakteri tersebut ke dalam alat kelamin.

\section{KESIMPULAN DAN SARAN}

Terdapat hubungan yang bermakna antara penggunaan jenis pembalut dengan kejadian keputihan. Diharapkan selalu berusaha menjaga kebersihan kewanitaan dengan menggunakan pembalut yang terjaga kebersihannya.

\section{DAFTAR PUSTAKA}

Clayton, C. (2008). Keputihan dan Infeksi Jamur Kandida lain. Arcan.

Johar, Wiwin., Rejeki, Sri., Khayati, N. (2013). Persepsi dan Upaya Pencegahan Keputihan pada Remaja Putri di SMA Muhammadiyah 1 Semarang. Jurnal Keperawatan Maternitas, 1(1), 37-45. https://jurnal.unimus.ac.id/index.php/JK Mat/article/view/931

Murtiastutik, D. (2010). Buku Ajar Infeksi Menular Seksual. Airlangga University Press.

Persia, A., Gustia, R., \& Bahar, E. (2015). 
Hubungan Pemakaian Panty Liner dengan Kejadian Fluor Albus pada Siswi SMA di Kota Padang Berdasarkan Wawancara Terpimpin (Kuisioner). Jurnal Kesehatan Andalas, 4(2), 509512. https://doi.org/10.25077/jka.v4i2. 284.

Pribakti. (2012). Tips dan Trik Merawat Organ Intim: Panduan Praktis Kesehatan Reproduksi Wanita (Cet. 2). Sagung Seto.
Susanti, E. M., \& Wijaya, P. S. (2018). Perbedaan Penggunaan Pembalut Dan Pantyliner Jenis Biasa, Herbal, Dan Kain Dengan Kejadian Keputihan. Indonesia Jurnal Kebidanan, 2(1), 31. https://doi.org/10.26751/ijb.v2i1.427.

Wati, P. S., Ririanty, M., \& Nafikadini, I. (2019). Perilaku Menjaga Kebersihan Organ Genitalia pada Konsumen Pembalut Herbal. Jurnal Kesehatan, 7(1), 20-29. 